TITLE:

\title{
RECORDS OF LEARCHIS INDICA BERGH, 1896 FROM JAPAN AND HAWAII (NUDIBRANCHIA: EOLIDOIDEA)
}

\author{
$\operatorname{AUTHOR(S):~}$ \\ Baba, Kikutaro
}

\section{CITATION:}

Baba, Kikutaro. RECORDS OF LEARCHIS INDICA BERGH, 1896 FROM JAPAN AND HAWAII (NUDIBRANCHIA : EOLIDOIDEA). PUBLICATIONS OF THE SETO MARINE BIOLOGICAL LABORATORY 1969, 16(6): 399-403

\section{ISSUE DATE:}

1969-03-31

URL:

http://hdl.handle.net/2433/175561

RIGHT: 


\title{
RECORDS OF LEARCHIS INDICA BERGH, 1896 FROM JAPAN AND HAWAII (NUDIBRANCHIA : EOLIDOIDEA) ${ }^{\text {l) }}$
}

\author{
KiKUTARO BABA \\ Biological Institute, Osaka Kyoiku University, Tennoji, Osaka, Japan \\ With Plate XXVII
}

Long since, I have had many chances to collect and observe an eolidoid nudibranch that bears clusters of brilliant vermilion-red gills on the back which are each marked with a black spot down the tip. Of course, I have made several examinations on these specimens, but left them for a long time without making definite reference to species.

Recently nineteen specimens of a nudibranch were sent to me for identification, together with two transparencies showing the colouration of live specimens, by $\mathrm{Mr}$. G.A. Robilliard of the Friday Harbor Laboratories, University of Washington. These specimens were collected by himself while he was working in Hawaii with the feeding ecology and energetics of the nudibranch. Seeing them and to my astonishment, I immediately found that they resembled so closely the above-mentioned Japanese specimens in their body appearance as well as in their body colouration that the former was to be identified with the latter. And this urged me to publish the following result of identification, together with the full description, so hurriedly.

For their kindness in making their valuable specimens available for my study, I wish to thank: the Chief of the Biological Laboratory, Imperial Household; Mr. Torao Yamamoto of the Toyo Junior High School; Mr. Iwao Hamatani of the Osaka Kyoiku University; Dr. Yoshiharu Honma of the Niigata University; Dr. Itaru Usuki of the Sado Marine Biological Station; Mr. Takeo ABE of the Takaoka Senior High School; and Mr. Gordon A. Robilliard of the Friday Harbor Laboratories.

\section{TAXONOMY}

Family Facelinidae BerGH, in CARUS, 1889

Genus Learchis BERGH, 1896

Type: Learchis indica Bergh, 1896

1) Contributions from the Seto Marine Biological Laboratory, No. 506.

Publ. Seto Mar. Biol. Lab., XVI (6), 399-403, $1969 . \quad$ (Article 31) 


\section{Learchis indica BERGH, 1896}

(Japanese name: Hibusa-mino-umiushi)

Learchis indica BERGH, 1896, pp. 386-389, pl. 16, figs. 1-4.-Amboina.

Aeolidia dangeri RisBec, 1928, pp. 252-254, pl. 9, fig. 1, text-fig. 82.-N. Caled.

Hervia dangeri: RISBEC, 1953, pp. 136-138, fig. 75a-f.-N. Caled.

Learchis howensis BuRN, 1966, pp. 25-26, figs. 7-10.--Lord Howe I.

The species indica was established originally on a single preserved specimen from Amboina. Thus the colour of the live animal remains unknown. The annulated state of rhinophores is presumably owing to preservation. The facelinid type of the gill arrangement, the non-indented jaws, and the conical and unarmed penis seem to characterize the species so distinctly that the specimens occurring in Japan and Hawaii which are provided with all of such essential specific features mentioned just above may safely be identified with $L$. indica. Also it is suggested here that both of dangeri (see MARcus, 1958, p. 58; Marcus \& Marcus, 1960, p. 183) and howensis actually constitute junior synonyms of indica. L. poica MArcus \& Marcus, 1960 from Florida, West Indies and Ghana is another species of the same genus that differs from $L$. indica in the horseshoe formation of the left posterior liver (see Burn, 1966, p. 26) and in the possession of a penis provided with penial glands.

The sources of material for my study are listed below:

I. From the Pacific coasts of Japan:

1. Hayama, Sagami Bay (July 26, 1950, coll. by Biological Laboratory, Imperial Household, U. No. 322, Sp. No. 698, Det. No. 582). 1 sp.

2. Seto, Kii (Jan. 27, 1957, coll. by Yамамото). 1 sp.

3. Tomogashima, Osaka Bay (July 16, 1954, coll. by Hamatani). $1 \mathrm{sp.}$

II. From the Japan Sea coasts of Japan:

4. Nou, Niigata Pref. (July 29, 1958, coll. by ABE). 1 sp.

5. Awashima, Niigata Pref. (July 21, 1961, coll. by ABE). 1 sp.

6. Vicinity of the Sado M.B.S., Sado Is. (Aug. 8, 1955, coll. by Honma). 2 sps.

7. Locality as above (July 9, 1965, coll. by UsukI). 5 sps.

8. Locality as above (Apr.-Sept. 1966, coll. by UsukI). 22 sps. A series of additional specimens were procured by Usuki and BABA from about the same locality on July 10, 1968.

9. Ogi, Toyama Bay (Aug. 5, 1962, coll. by ABE and BABA). 1 sp.

10. Akazumi, Ishikawa Pref. (Aug. 8, 1967, coll. by ABe and BABA). 1 sp.

11. Ayukawa, Fukui Pref. (Aug. 6, 1964, coll. by ABE and BABA). 1 sp.

12. Echizen-cho, Fukui Pref. (Aug. 12, 1966, coll. by ABE and BABA). I sp.

III. From the Hawaiian waters:

13. Hawaii (during summer 1968, coll. by RoBILLIARD). 19 sps. 
As the first step of observations, nearly all of the specimens were examined in a living state by the original collectors to record their colouration in figures or photographs. Especially, the specimens Nos. 5 and 6 were prepared in serial horizontal sections for the decisive studies of the internal structures.

One of the Hawaiian specimens was dissected to confirm some internal characters such as jaws, radula and penis which are useful for identification. The personal information from Mr. RobILLIARD shows that his specimens were found feeding exclusively on an athecate hydrozoan, a species of Pennaria growing in shallow water.

Description: The general body-form is characteristic of the Facelinidae. The length (Code Ac) of the animal varies roughtly from 15 to $25 \mathrm{~mm}$. The cephalic tentacles are exceedingly slender. The rhinophores are shorter and entirely smooth in a fresh state, but in preservation some slight constrictions may appear along the length. The foot-corners are tentaculiform. The tail is short and tapering behind. The liver system in Learchis was revealed also to assume the construction characteristic of the Facelinidae (see BABA, 1965: Facelinella): the branchial rows belonging to the left posterior liver are gathered to form a series of clusters on each back-margin. The right liver (and its partner on the left side) consists of 5-7 oblique rows. The papillae are deciduous, of an elongated fusiform in a full extension, and about 8 in number at the maximum on the largest rows. The relative positions of the genital orifice, nephroproct and anus to the liver system are shown in the annexed figure.

The colouration of the body may vary greatly in details according to specimens. The general colour of the back and sides is whitish, whitish yellow, or pale vermilion. The head is intensively tinted with vermilion-red, showing always a whitish or yellowish $\mathrm{V}$-shaped pattern between the cephalic tentacles and rhinophores. Sometimes the pattern in question extends rearward as a median line to tail, branching around the pericardium to embrace it. Both of the cephalic structures are usually opaque yellow (rarely opaque white) above, and deep vermilion-red below. The anterior margin of the foot is opaque yellow. The median crest of the tail is also opaque yellow. The sole colourless. Occasionally there are faint vermilion mottlings on each side below the branchial tufts. The integument of each branchial papilla is as a rule vermilion-red below, and opaque yellow towards the tip. There is an azure marking on the exterior of the papilla immediately below the opaque yellow cap. The vein (=liver diverticulum) of the papilla is dark yellowish brown throughout its length, but with a marked accumulation of melanin pigment granules within the diverticular epithelium near its upper extremity (see HAefelfinger, 1960: Caloria maculata; Marcus, 1955: Phidiana selenkai; BuRN, 1966: Facelina newcombi).

The jaw-plates in Learchis is distinguished from those of Caloria (cf. HAEFELFinger, 1960) by having no dorsal indentation. Their masticatory edge bears a series of 9-25 simple denticles. The radular formulae in the specimens dissected ranged from $15 \times 0.1 .0$ to $25 \times 0.1 .0$ The central tooth is typically horseshoe-shaped, narrow, bearing 5-7 denticles on each of the median cusp which is smooth, or rarely provided 
with 1-2 lateral denticulations. The liver diverticulum within each branchial papilla has a thickly corrugated wall so that the whole structure shows a racemose appearance even when the papilla is fully extended (see RisBec, 1928, p. 254). As noted previously by BERGH, 1896, the penis of Learchis is simply conical without apical stylet. The vas deferens is prostatic; it passes directly into the penis which is destitute of penial glands. There is a saccular spermatocyst. The ampulla is thick, and more or less winding. At Sado this species is said to spawn most actively during August (personal communication from Dr. Usukr).

\section{REFERENCES}

BABA, K. 1965. The anatomy of Facelinella quadrilineala (BABA) (Nudibranchia-Eolidoidea). Publ. Seto Mar. Biol. Lab., vol. 12, no. 5.

Bergh, R. 1896. Eolidiens d'Amboine. Rev. suisse Zool., tom 4, no. 2.

Burn, R. 1966. Descriptions of Australian Eolidacea (Mollusca : Opisthobranchia). 4. The genera Pleurolidia, Fiona, Learchis and Cerberilla from Lord Howe Island. Journ. Malac. Soc. Australia, no. 10.

EDmunds, M. 1964. Eolid Mollusca from Jamaica, with descriptions of two new genera and three new species. Bull. Mar. Sci. Gulf \& Carib., vol. 14, No. 1. (p. 18, Learchis poica).__ $1968 . \quad$ Eolid Mollusca from Ghana, with further details of West Atlantic species. Bull. Mar. Sci., vol. 18, no. 1. (p. 208, Learchis poica)

Haefelfinger, H.-R. 1960. Neue und wenig bekannte Opisthobranchier der Gattungen Trapania und Caloria aus der Bucht von Villefranche-sur-Mer (A.-M). Mitg. Gen. Schw. Zool. Ges. Basel. (p. 234, Caloria maculata)

Lemche, H. 1964. Facelina Alder \& HANcock, 1855 (Gastropoda): proposed addition to the Official List. Z. N. (S.) 1104. Bull. Zool. Nomencl., vol. 21, pt. 1. (p. 49, Facelininae)

Marcus, Er. 1955. Opisthobranchia from Brazil. I. Bol. Fac. Fil. Ciên. Letr., Univ. São Paulo, Zoologia, no. 20. (p. 178, Phidiana selenkai). —— 1958. On western Atlantic opisthobranchiate gastropods. Amer. Mus. Novitates, no. 1906. (p. 58, Learchis)

Marcus, Ev. \& MARcus, Er. 1960. Opisthobranchs from American Atlantic warm waters. Bull. Mar. Sci. Gulf \& Carib., vol. 10, no. 2.

Risbec, J. 1928. Contribution a l'étude des nudibranches Néo-Calédoniens. Faune Colon. Franç., tom. 2. — 1953. Mollusques nudibranches de la Nouvelle-Calédonie. Faune de l'Union Franç., vol. 15.

Risso-Dominguez, C. J. 1963. Measuring nudibranchs: a standardization for descriptive purposes. Proc. malac. Soc. London, vol. 35, pt. 5. 


\section{EXPLANATION OF PLATE XXVII}

Learchis indica BERGH, 1896

Fig. 1. Ayukawa, Fukui Pref. (Aug. 6, 1964).

Figs. 2, 4, 8. Ogi, Toyama Bay (Aug. 5, 1962).

Figs. 3, 5, 7. Sado Is. (Apr.-Sept. 1966).

Fig. 6. Sado Is. (Aug. 8, 1955).

Fig. 1. Entire animal in an actively crawling position. Measurements after Code system proposed by Risso-Dominguez, 1963: A. $25 \mathrm{~mm}$; Ac. $22 \mathrm{~mm}$; T. 7 $\mathrm{mm}$; R. $3 \mathrm{~mm}$; C. $3 \mathrm{~mm}$; Bc. $4 \mathrm{~mm}$; Px. $4 \mathrm{~mm}$. a. a small accumulation of melanin, b. a greater accumulation of melanin, c. opaque yellow cap, $d$. melanin black spot shining through, e. azure marking on the outer side of the papilla.

Fig. 2. Digestive system, diagrammatic. a. right liver, b. genital orifice lying below the last row of the right liver, c. reno-pericardial canal in cross section, $d$. nephroproct, e. anus, f. left posterior liver, g. left anterior liver, h. salivary gland.

Fig. 3. A left jaw-plate from outside $(\times 20)$.

Fig. 4. A radular tooth from above $(\times 130)$.

Fig. 5. A radular tooth from side $(\times 210)$.

Fig. 6. A kidney from above $(\times 13)$. a. nephroproct.

Fig. 7. Genital organs from above. a. prostatic vas deferens, b. penis, c. outer oviduct, d. accessory female glands, e. ciliated wall of the spermatocyst, $f$. ampulla. Anatomically the male orifice is situated just above the female one.

Fig. 8. Penis enclosed within a penial sac $(\times 25)$. 
Publ. Seto Mar. Biol. Lab., XVI (6), 1969.

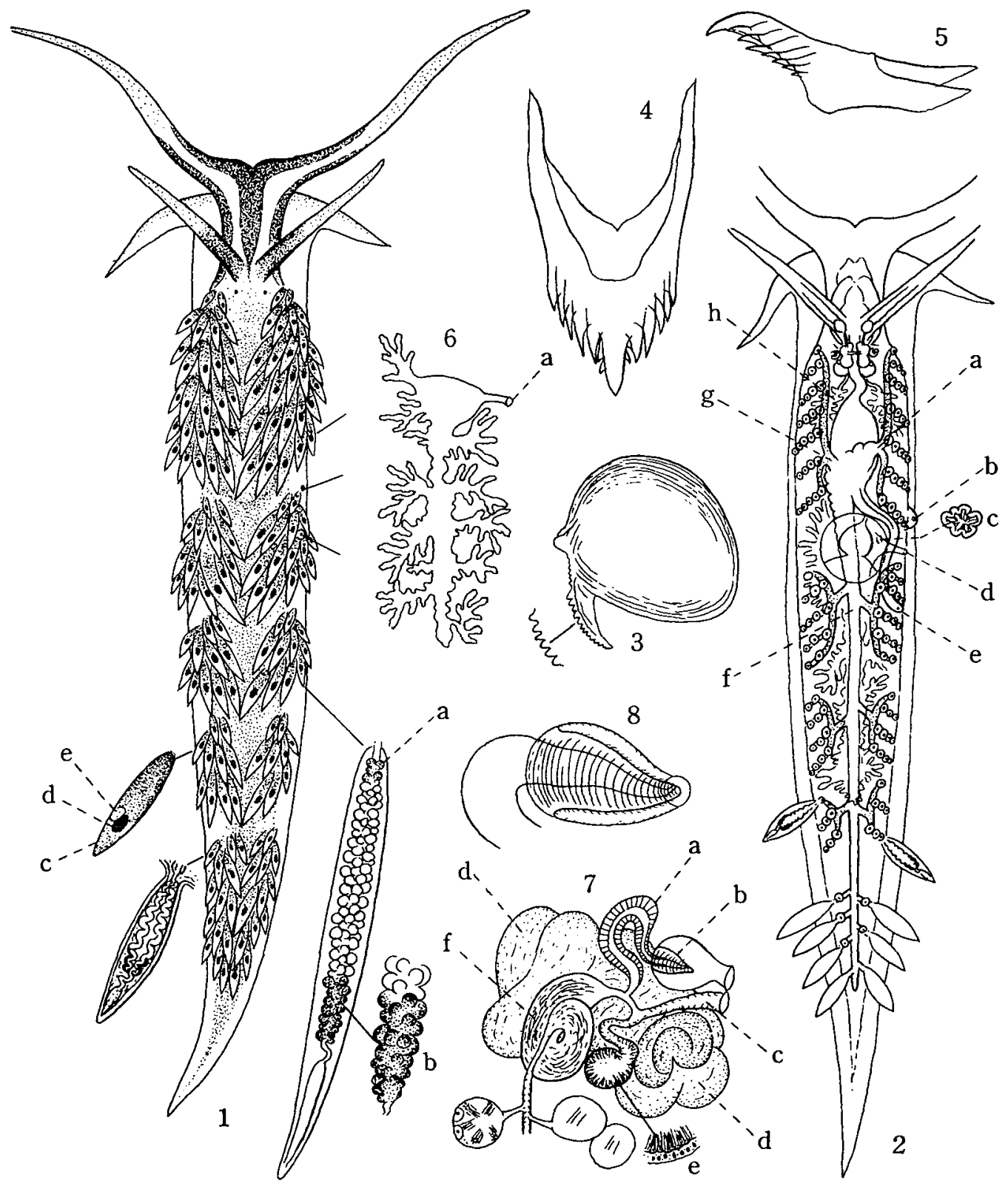

K. BABA : Learchis indica from Japan and Hawaii 